\title{
FOUR LETTERS OF MR. JUSTICE FIELD
}

\author{
Edited by HOWARD JAY GRAHAM $†$
}

FOREWORD

IN JUNE, 1937, the Library of the University of California acquired four letters written by Stephen J. Field, Associate Justice of the Supreme Court of the United States, to John Norton Pomeroy, ${ }^{1}$ first Professor of Municipal Law in Hastings Law College. The letters were acquired from Mrs. Walter Schirmer, of Carmel, California, widow of John Norton Pomeroy, Jr. They are of extraordinary historical interest. They constitute an intimate record of those years during which Justice Field's friends were actively working in his behalf for the Democratic nomination as President, and during which he himself was often disheartened by the reluctance of a majority of the Supreme Court to broaden judicial review in accordance with the tenets of his laisses faire, natural rights philosophy. Requiring almost no clarification, and serving as an admirable supplement to Professor Swisher's biography, Stephen J. Field, Craftsman of the Law, ${ }^{2}$ the letters are here published by permission of the University of California.

I.

Supreme Court of the United States

My Dear Sir:

Washington, June 21st, 1881.

Some months ago I wrote to you respecting the sketch ${ }^{8}$ of a certain person's Legislative and Judicial work, and stated that it was so strong in its award of commendation that I should hardly dare show it to my friends. However, I have shown it to many of them and all have expressed a desire that it should be put in type. So I have concluded to give it to the printer. The book of comments upon my opinions and of extracts from them will be enlarged by additions relating to inter-

†Research Fellow in Political Science, University of California.

The editor of these letters is indebted to Professor Charles Aikin of the University of California for guiding the research wherein they were discovered.

1. See "John Norton Pomeroy," by John Norton Pomeroy, Jr., Great Auericars Lawyers, VIII, 91-135 (Philadelphia, 1909) edited by William Draper Lewis; at 123124.

2. Brookings, 1930.

3. During the winter of 1880-81, Professor Pomeroy had written the appreciative review of Justice Field's career eventually published as the "Introductory Sketch" in Some Account of the Work of Stephen J. Field, edited by Black and Smith, privatcly printed, 1881. 
State commerce, taxation, attorneys and counsellors at law, the Pueblo of San Francisco and the treatment of the Chinese in California. With your sketch prefixed the book will be valued by my friends.

But your sketch has been altered in several particulars. Much of its strong language of commendation has been omitted, and some of it has been modified, and in these respects I think the sketch will be more acceptable to others as it is to myself. The severe. condemnation you expressed of the old Supreme Court of the State is also omitted. It still states-what is true-that the court did not at all times have the confidence of the public, but that this was owing to the character-intellectual and moral - of persons who are now dead. The living members of the old court are Judge Hastings " - the founder of your Law Department, Judge Hydenfeldt, ${ }^{5}$ Judge Bennett, ${ }^{6}$ Judge Burnett ${ }^{7}$ and Judge Terry. ${ }^{8}$ No one ever questioned the integrity or ability of Hydenfeldt and Bennett, or the integrity of Burnett or Terry. Hastings you know, and he was never regarded as a shining light. Terry had ability but his Southern prejudices and partizanship affected his judgment. The judges who brought the greatest reproach upon the bench, were Wells, ${ }^{0}$ Murray ${ }^{10}$ and Anderson, ${ }^{11}$ all of whom are dead. I think the sweeping language you used would create much unpleasant feeling.

The common law of England was adopted as a rule of decision in the courts by the first Legislature in April 1850.

4. Serranus Clinton Hastings, 1814-1893, Chief Justice of Supreme Court of Iowa 1848-1849; first Chief Justice of Supreme Court of California, 1849-1851; Attorney General of California, 1852-1854. In 1878 Hastings provided an endowment of $\$ 100,000$ for the founding of Hastings College of the Law. See 8 Dicr. Aur. Broc. 387.

5. Solomon Heydenfeldt, 1816-1890. Associate Justice of Supreme Court of California 1850-1857. See Shuck, A History of the Bencr ard Bar of Carifoania, (1901) pp. $457-459$.

6. Nathaniel Bennett, 1818-1886. Associate Justice, Supreme Court of California 1849-1851. See SHuCr, op. cit. supra note 5, at 445-447.

7. Peter Hardeman Burnett, 1807-1895. Judge of Supreme Court of Oregon 1845; appointed Associate Justice of Supreme Court of Oregon Territory by President Polk 1848. First Governor of California 1849-1851; Associate Justice of Supreme Court of California, January, 1857, to September, 1857. See 3 Dict. A2r. Broc. 300-301.

8. David Smith Terry, 1823-1889. Associate Justice, Supreme Court of Californiz, 1855-1857; Chief Justice, 1857-1859; later, as a result of affairs growing out of the Sharon Will Case, a bitter personal and political enemy of Field. See 18 Dict. Azs. Biog. 379-380; Swisher, op. cit. supra note 2, pp. 321-361 ("The Terry Tragedy:")

9. Alexander Wells, ?-1854. Associate Justice of the Supreme Court of California, January, 1853 to October, 1854.

10. Hugh C. Murray, 1825-1857. Associate Justice of Supreme Court of California, 1851-1852, Chief Justice, 1852 to 1857. See Suucr, op. cit. supra note 5, at 435-436.

11. Alexander Anderson, ?-1853. Associate Justice of Supreme Court of California, April, 1852, to January, 1853. 
I was a member of the second one. Some changes were required in your article in consequence of this misapprehension. [See page 15.]

The statement of my views in Washburn vs. Perry, ${ }^{12}$ the Legal Tender case in the Supreme Court of the State, and in the granger cases ${ }^{13}$ in the Supreme Court of the United States, is not strictly accurate. Although I have always held that the States can collect their taxes in such way as they might choose -in goods, (as was formerly done in Virginia, in tobacco) or in coin or notes, and that their power in this respect could not be controlled by Congress, I did not express it in the State Supreme Court. I suggested it to Chief Justice Chase in the case of Lane County vs Oregon, ${ }^{14}$ and he expressed my vicws. In the granger cases I did not place my dissent on the interference of the State Legislation with the power of Congress under the commercial clause. I have accordingly corrected your sketch in these particulars. But the general analysis of the labors of your friend remain unchanged.

Please look over the accompanying sheets and if you approve of the sketch in its present form it will be published, otherwise not. Whatever appears in print must have your sanction as it will bear your name as its author. Of course you will alter it to suit your own views if you think it necessary. Make such changes as you like bearing always in mind, if you will pardon me, that its language is already as eulogistic as justice will permit. When you have corrected it please return it to me. I will ask your early attention to this as I wish to have the matter completed before I leave for Europe this coming month. It is my present purpose to leave between the 5th and 10th of July.

On Sunday last Mr. Lloyd Tevis, ${ }^{18}$ of San Francisco, passed several hours with me and in the course of conversation with him reference was had to the Pacific Railway Company and the want of tact in the management of its affairs. This led me to mention the letter that I wrote to Mr. Towne ${ }^{10}$ urging the officers of the company to retain your professional services. I told Mr. Tevis of your ability as a legal writer, of your frequent communications to law journals and of your special study of questions in which the Railway was interested. I ob-

12. 20 Cal. 318 (1862).

13. Munn v. Illinois, 94 U. S. 113 ; Chicago, B. \& Q. R.R. v. Iowa, 94 U. S. 155; Peik v. Chicago \& N. W. R.R., 94 U. S. 164; Chicago, M. \& St. P. Ry. v. Aclley, 94 U. S. 179; Winona and St. Peter R.R. v. Blake, 94 U. S. 180; Stone v. Wisconsin, 94 U. S. 181. (all 1877).

14. 74 U. S. 71 (1869).

15. Lloyd Tevis, 1824-1899, President (1872-1892) Wells Fargo Express Company, and a former President of the Southern Pacific Railroad. See 18 Dicr. AM. Broc. 384385.

16. General Manager of the Central Pacific and Southern Pacific Railroads, 1883. 
served that the company would act wisely if it retained you and he agreed with me fully and added, that he would speak to the officers on his return to San Francisco and urge them to retain your services.

Mr. Tevis is a very efficient man in all matters of business, has great tact and good sense and is more likely to effect an arrangement of the kind than any person that I know of. If you will consult him on the subject-and indeed on any matters of business, you will find him of invaluable service; and he is faithful in all things.

Please let me hear from you as soon as you can conveniently examine the accompanying papers.

With kind remembrances to Mrs. Pomeroy, I am

Very truly yours,-

Stephen J. Field

Prof. John Norton Pomeroy

of University of

California

II.

My dear Professor Pomeroy:-

Washington, D. C.

April 14th 1882

Your letter of the 1st inst. was received yesterday.

I have, today, mailed a copy of the volume containing "some account of my legislative and judicial labors" to the several persons named in the list which you inclosed. As I am not acquainted with any of the gentlemen, I wrote on the corner of the book, outside, "From J.N.P."; which, I suppose, is what you desired-thus showing that it was forwarded at your request. I shall be glad to send a copy to any other persons whom you may suggest.

I lately met a lawyer in this city, of marked ability, Professor Maury by name, who delivers lectures in the Law School of Columbia College, \& who will, probably, soon be appointed Assistant Attorney General; and he told me, that he had read the first volume of your work on Equity Jurisprudence, ${ }^{17}$ with the greatest admiration and instruction; that he considered it vastly superior to the work by Storey on the same subject. He added, that in a late conversation he had with Judge Bradley of our Court, the Judge expressed the same opinion to him. I requested him to write.a Review of the book for one of the law magazines; and he promised me to do so. I mentioned to you, in one of my letters, that I received the first volume on the

17. A Treattse on Equity JuRisprudence, as Adumistempd in the UzitTED

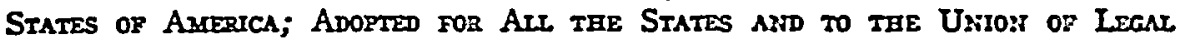
and Equitabte Rearedies Under the Rerozkred Peocedurz San Francisco: A. L. Bancroft, 1881-1883, 3 vols. 
eve of my departure to Europe last summer. Since my return I have been so occupied that I could scarcely find time to answer my letters. I have not, therefore, read the book, except a few pages here and there. I saw enough, however, to greatly interest me; and as soon as the Court adjourns in May, I shall give it a careful perusal: I doubt not that it possesses all the merit which characterises your writings.

I see that California is very much excited over the veto of the Chinese Bill by the President. ${ }^{18}$ I do not wonder at it. It must be apparent to every one, that it would be better for both races to live apart-and that their only intercourse should be that of foreign commerce. The manners, habits, mode of living, and everything connected with the Chinese prevent the possibility of their ever assimilating with our people. They are a different race, and, even if they could assimilate, assimilation would not be desirable. If they are permitted to come here, there will be at all times conflicts arising out of the antagonism of the races which would only tend to disturb public order and mar the progress of the country. It would be better, therefore, before any larger number should come, that the immigration be stopped. You know I belong to the class, who repudiate the doctrine that this country was made for the people of all races. On the contrary, I think it is for our race-the Caucasian race. We are obliged to take care of the Africans; because we find them here, and they were brought here against their will by our fathers. Otherwise, it would be a very serious question, whether their introduction should be permitted or encouraged.

I expect to leave Washington, about the last of May or first of June, for California; and when there I hope I shall have the pleasure of spending some pleasant hours with you.

Please present my kind regards to Mrs. Pomeroy, \& believe me

Professor J. N. Pomeroy.

Very sincerely yours,

Stephen J. Ficld

III.

My dear Mr. Pomeroy:

Washington, D. C., March 28th 1883

Yesterday Mr. Waeger Swayne, ${ }^{19}$ a partner of Judge Dil$\operatorname{lon}^{20}$ of New York called to see me, and in the course of con-

18. President Arthur had vetoed the Chinese Exclusion Act, April 4, 1882.

19. Wager Swayne, 1834-1902, Yale 1856. Son of Field's former colleague, Justice Noah H. Swayne. See 18 Dicr. Ax. Biog. 240-241.

20. John Forrest Dillon, 1831-1914. United States Circuit Judge for the Eighth Judicial Circuit, 1869-1879. See 5 Drct. Am. Broc. 311. 
versation he stated that he was desirous of securing for one of our law magazines a careful review of the recent decisions of the Supreme Court in the Louisiana and Virginia cases, ${ }^{21}$ and asked me whether you would be likely to furnish an article on that subject if applied to, the usual compensation for such articles being given.

I said in reply that I thought you would. He will accordingly write to you on the subject in the course of a few days, having first inquired of the magazine editors whether such an article would be acceptable to them. ${ }^{20}$

The recent decisions of our Court in those cases have provoked a great deal of comment and much hostile criticism. I do not myself see how it is possible to sustain the decisions of the majority of the Court without overturning a whole line of decisions commencing almost with the foundation of the Government. However, that is a matter which you can better judge of when you have read the opinions.

A few days since I sent you a copy of the opinions in the Virginia cases. ${ }^{23}$ I will today send you a copy of those in the Louisiana cases. ${ }^{24}$ They certainly either constitute a new departure for the Court, or the profession has been greatly mistaken as to the purpose and effect of its previous decisions.

21. On March 5, 1883, the Supreme Court had decided the so-called Repudiation Cases (107 U. S. 711) involving the power of various Southem States to readjust the huge debts piled up by the corrupt carpet bag regimes in the years immediately following the Civil War. As in all Reconstruction cases, issues were hopelessiy confused, and the majority opinion, written by Chief Justice Waite, denied the competency of the Court to compel States to meet their obligations. Justices Field and Harlan dissented. See Wilitakr A. Scotr, The Repudiation of State Debts (N. Y., 1893) Chapter VI, "Repudiation in Virginia;" Ella LoNe, Reconstruction is Louisinain After 1868, (N. Y., 1918) passim, for historical background.

22. Professor Pomeroy's attack on the trend of constitutional interpretation as then evidenced by the majority decisions in Munn v. Illinois and Ex Parte Wall, 107 U. S. 265, 1883, (as well as in the Repudiation cases) appeared in 17 American Lay Review 694 734 (September-October 1883, "The Supreme Court and State Repudiation.") Reprinted in pamphlet form, it attracted wide attention. (John Norton Pomeroy, Jr, supra note 1, at 108). Today the article is notable as an analysis and criticism of the tendency of the early Waite Court to interpret narrowly limitations on legislative power: to huld, as Pomeroy said, (p. 703) that these "be strictly construed in favor of the government;" that "nothing . . . be added to their express terms by implication or inference." Decrying this tendency as one both "subversive" and "erroneous," in that it left property" rights subject to "injurious and communistic legislation," Pomeroy hailed Field's minority views as the hope of the future.

Stricken with pneumonia early in 1885, Professor Pomeroy did not live to see the reversal of the trends he deplored.

23. Antoni v. Greenhow, 107 U. S. 769 (1883).

24. Louisiana v. Jumel; Elliott v. Wiltz, 107 U. S. 711 (1883). 
Some weeks ago, I wrote you with reference to the San Mateo tax case ${ }^{25}$ telling you that its decision would not be made until next term, and enclosing you also certain memoranda which had been handed me by two of the Judges. Have you ever received these? They were, of course, intended only for your eye, and I should be glad to know that they have come to your hands.

I shall leave here for San Francisco about the first of June. I may perhaps stop at Carson City on the way, to hold Court for a few days there.

I shall be ready to take up any new tax cases $^{20}$ as soon as I arrive, and I hope in whatever case is tried all the facts relating to the mortgage upon the property of the Railroad Company will be shown and also the extent to which its property has been subjected to taxation throughout the State.

I take the Argonaut, 27 from San Francisco, and I-see no other California paper, except occasionally. Now and then some good friend will send me the Chronicle, containing either a direct attack or some base insinuation. But for newspaper attacks I have long since ceased to care. They do not worry me at all. As I have often said, if my opinions present the law truly they will ultimately be sustained, though accompanied with censorious criticism on all sides on their first appearance. On the other hand, if they do not present the law truly, they will ultimately go down and be disregarded, though accompanied at first with the praises of the whole community. Their proper. place must be ultimately determined by the profession of the whole country. As for personal attacks upon my motives I care not. So long as I retain a consciousness of having endeavored to do my duty, I shall not be troubled by what others say of my action.

Please present my kindest regards to Mrs. Pomeroy whose health, I hope, has been entirely restored before this. Mrs.

25. County of San Mateo v. Southern Pacific Railroad Co., 13 Fed. 145, 722, decided by Justice Field at Circuit, September 25, 1882. Appealed to the Supreme Court of the United States, argued December 19, 20, 21, 1882, decided December 21, 1885. (116 U. S. 138). See Swisher, op. cit. supra note 2, Chapter IX. The story of these cases deserves more than passing mention. Fuller treatment is contemplated in a later article.

26. Numerous cases involving issues subordinate to those of the San Mateo case were on the docket of the Circuit Court in San Francisco; and were decided by Justice Field on his next visit to the city in 1883. See County of Santa Clara v. Southern Pacific Railroad Company and cases reported therewith, 18 Fed. 385. Final decision in these cases was made by the Supreme Court of the Uaited States in MLay, 1886. (118 U. S. 394).

27. A well-written organ of conservative opinion edited by Frank Pixley. 
Field unites with me in kind remembrances both to her and her daughter.

Prof. John Norton Pomeroy.

Very sincerely yours,

Stephen J. Field

IV.

My Dear Mr. Pomeroy:

Washington, D. C.

July 28th 1884.

Your very welcome letter of June 21st was received some weeks ago. Many thanks for all the kind words and kind offers it contains.

Had my name been successful at the Chicago Convention ${ }^{23}$ I should not have hesitated to have called upon you for the addresses to which you refer. But as that Convention has put another in nomination, my political life may be considered as substantially at an end. It is not at all likely that my name will ever again be used in connection with any political office. I had, of course, some ambition to carry out certain measures which I believed would be of great advantage to the country. Particularly did I desire a reorganization of the Federal Judiciary. As now constituted it fails of the purpose of its creation. The Supreme Court is three years behind in its regular business, and its docket is increasing from year to year so rapidly that it will soon be four years, and more, before a case can be reached after it is docketed. Could I have been instrumental in reorganizing the Federal Judiciary I would have placed on the Bench able and conservative men and thus have brought back the decisions of the Court to that line from which they should not have departed and thus, as I believe, have contributed something towards strengthening and perpetuating our institutions. There were also many other measures of great importance to the country, like the improvement of the Mississippi River and connecting it with the Lakes; the revival of our commercial marine and the revision of the tariff, to the success of which I might have contributed. But all this must be placed in the category of dreams that might have been but will not be realized.

I shall have much to say to you when we meet; particularly of the very strange action in California. Had I received the

28. Meeting in Chicago on July 8, 1884, the Democratic National Convention had nominated Grover Cleveland. Justice Field's name had been rendered unavailable as a result of party strife in California. See Swishen, op. cit. sispro note 2, at 300-310.

29. Justice Field's plan for reorganizing the Federal Judiciary will be outlined in a separate article. 
cordial support, instead of opposition of that State my candidacy, according to the judgment of my friends, would have stood great chances of success; and even without that support, had the forces of Mr. Cleveland ever given way my name would have been presented at Chicago with reasonable prospect of success. At least, so all my friends say. But I am content where I am. There at least I have no caprices to consult and no clamors to fret me.

My brother Cyrus ${ }^{80}$ will start for Oregon by the Northern Pacific route on the 23rd of August and he has invited me to accompany him and I have accepted his invitation. We shall reach Portland about the 30th. After holding court there a few days I shall proceed to San Francisco and remain in California two or three weeks. I do not expect to hold court there more than one or two days.

With kind regards to Mrs. Pomeroy, I am, Very sincerely yours,

Prof.

Stephen J. Field

John Norton Pomeroy.

30. Cyrus W. Field, 1819-1892, promoter of the Atlantic cable. See 6 Dicr. Axs. Broc., pp. 357-359. 